\title{
Re-Dramatizing the Palestinian-Israeli Conflict: Representations of Trauma and Postmemory in Caryl Churchill's Seven Jewish Children: A Play for Gaza (2009)
}

\author{
Dr. Reem Ahmed A. EI Bardisy \\ An Assistant Professor of English Literature \\ Women's College for Arts, Science and Education, Ain Shams University
}

\begin{abstract}
Caryl Churchill's Seven Jewish Children (2009) is a play that presents a non-Jewish and non-Western view of the Palestinian- Israeli conflict. It emphasizes some beliefs and counter-beliefs regarding this conflict and shows how it is perceived within the Israeli community. Because of the state of 'counter acting- out' that the dramatist accentuates in this play, she has been severely attacked by many critics who regarded her as anti-Israeli and considered the play antiSemitic. This paper emphasizes the representations of trauma and postmemory in Seven Jewish Children and underscores the collective trauma of some Jews who are afraid of the impact of their traumatic history and postmemories on their descendants. Moreover, it underscores the different strategies which these Jewish elders use to protect their children from the impacts of trauma and postmemory. Furthermore, it stresses the role of theatre as a counter-hegemonic mechanism that can deconstruct misconceptions and present a different version of history.

Key Words

trauma, postmemory, the Palestinian- Israeli Conflict, antiSemitism, acting-out, counter acting-out.
\end{abstract}


مجلة وادي النيل للاراسات والبحوث الإنسانية والاجتماعية والتربوية (مجلة علمية محكمة)

(ISSN : 2536 - 9555)

إعادة مسرحة الصراع الفلسطيني الإسرائيلي: تمثيل الصدمة والذكريات المتوارثة

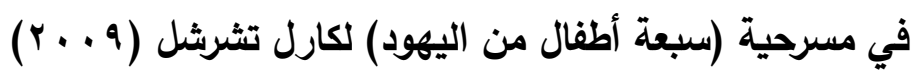

$$
\text { د. ريم احمد عبد الرحمن البرديسي }
$$

مدرس الأدب الإنجليزي بكلية البنات للآداب والعلوم والتربية-جامعة عين شمس لرس

الملخص العربي

مسرحية (سبعة أطفال من اليهود ...مسرحية لغزة) للكاتبة البريطانية الثهيرة

كارل تشرشل هي مسرحية تقدم رؤية مغايرة عن تلك التي تقدمها وسائل الإعلام الغربية عن الصراع العربي الإسرائيلي. تلقي الكاتبة الضوء علي بعض المعتقدات والمعتقدات المضادة المتعلقة بالصراع العربي الإسرائيلي وتوضتح كيف يُنظَر إلي هذا الصراع داخل المجتمع الإسرائيلي. وبسبب هذه الآراء المضادة التي عبرت عنها الكاتبة في هذه المسرحية فقد هوجمت هجوما شديدا من قِبَل بعض النقاد الذين اتهموها بمعاداة إسرائيل واعتبروا المسرحية معادية للسامية. يتتاول هذا البحث طرق تمثيل الصدمات والذكريات المتوارثة في مسرحية (سبعة أطفال من اليهود) ويلقي الضوء علي الصدمة الجماعية التي انتابت بعض اليهود من جرّاء الجرائم التي ارتكبوها في حق الفلسطينيين وكذلك خوفهم الثديد من تأثر أحفادهم بتاريخهم المؤلم والطرق المختلفة التي يتبعوها لحماية صغارهم من آثار تلك الصدمات والذكريات المتوارثة. كما يتتاول هذا البحث أيضا طرق تمثيل الصدمة في الأدب ودور المسرح في نقل وتمثيل الذكريات المتوارثة للأجيال الجديدة كما يُبرز دور المسرح في تقديم خطاب مغاير ونسخة مختلفة من التاريخ عن تلك التي تقدمها الأنظمة المهيمنة. كلمات مفتاحية: الصدمة- الذكريات المتوارثة- الصراع الفلسطيني الإسرائيليعداء السامية- المعتقدات والمعتقدات المضادة. 
Re-Dramatizing the Palestinian-Israeli Conflict: Representations of Trauma and Postmemory in Caryl Churchill's Seven Jewish Children: A Play for Gaza (2009)

Dr. Reem Ahmed A. El Bardisy

مجلة وادي النيل للار اسات و البحوث الإنسانية والاجتماعية والتربوية (مجلة علمية محكمة)

Seven Jewish Children: A Play for Gaza (2009) is a play written by the celebrated British dramatist Caryl Churchill (1938- ) in response to the 2009 Israeli martial attacks on Gaza. In this play, which surveys the history of Israel from the Holocaust to the invasion of Gaza in 2009, Churchill handles the Palestinian-Israeli conflict from diverse perspectives presenting a multiplicity of Jewish voices quite different from those we are used to hear in Western media. Interestingly, the playwright counters the assumptions posed by the mainstream Jewish discourse, offering an unconventional version of the Palestinian-Israeli conflict. In Seven Jewish Children, a group of Jewish elders argue about how to narrate a number of important historical events to an offstage child- who might represent all Jewish children- discussing what the children must know and must not know about the Palestinian-Israeli conflict. During the discussion, however, they come to realize that their children will not be proud of their Jewishness if they are told the bare truth. Hence, they eventually decide to hide some of the historical events from the children. The play forcibly underscores the collective trauma of these Jewish elders who are apparently troubled by the repercussions of historical aggression on their descendants. It underlines the conflict between beliefs and counter- beliefs and shows how the Palestinian-Israeli conflict is perceived within the Israeli community. Yet, though the writer emphasizes the Palestinian people's trauma of war, loss and diaspora, we still do not hear the voices of the Palestinians, as the play handles this crisis from a Jewish perspective.

This paper explores the representations of trauma and postmemory in Caryl Churchill's Seven Jewish Children. It researches the conflict between "acting-out' and 'counteracting-out' which runs through the Israeli community. It also deals with the collective memory of the Jews, as brought 
مجلة وادي النيل للاراسات والبحوث الإنسانية والاجتماعية والتربوية (مجلة علمية محكمة)

(ISSN : 2536 - 9555)

about by the elderly in the play, and brings to light these elders' preoccupation with their presumably collective guilt. Furthermore, the paper shows the impact that postmemory can have on the postgenerations as the Jewish elders are terrified of the effect of their historical postmemories on their children; hence, they try to tell traumatic events in a way that can save the children from inheriting their grandparents' legacy of trauma. Moreover, the paper reveals the different strategies that these Jewish elders adopt to save their children from the impact of postmemory and the agony of their trauma. Besides, referring particularly to the theories of Marianne Hirsch (1949- ) and Dominick LaCapra (1939- ), this paper underlines the role of theatre in transmitting postmemories and emphasizing their great impacts on ensuing generations. Further, it stresses the role of theatre as a counter-hegemonic mechanism that can deconstruct misconceptions and present a different version of history. In addition, this paper emphasizes how the dramatist uses some postdramatic elements to evoke the audience's ethical awareness of the Palestinian-Israeli Conflict.

\section{Trauma and Postmemory in literature}

The theme of "trauma" is one of the recurring themes in literature. Cathy Caruth (1955- ) defines trauma as "the response to an unexpected or overwhelming violent event or events that are not fully grasped as they occur, but return later in repeated flashbacks, nightmares and other repetitive phenomena"(91). It is a disconcerting and upsetting experience that causes psychological or physical harm and leads to long-lasting negative consequences. M. Balaev asserts that trauma refers to "an individual's emotional response to an experience that disrupts previously held perception of one's self and others"(150). It may affect the traumatized person's ability to cope with others and cause feelings of helplessness. 
Re-Dramatizing the Palestinian-Israeli Conflict: Representations of Trauma and Postmemory in Caryl Churchill's Seven Jewish Children: A Play for Gaza (2009)

Dr. Reem Ahmed A. EI Bardisy

جلة وادي النيل للاراسات و البحوث الإنسانية والاجتماعية والتربوية (مجلة علمية محكمة)

According to Jeffrey C. Alexander, cultural traumata occur when a group of people is exposed to a terrible event which is regarded by the members of this group as perilous and shocking. In order to be considered a cultural trauma, this event must have a scar on their group consciousness. This scar is expected to have a great impact on the memories of this group forever. Moreover, due to the impact of the collective memory, this cultural trauma can change the future identity of this group. He maintains: "Cultural trauma occurs when members of a collectivity feel they have been subjected to a horrendous event that leaves indelible marks on their group consciousness, marking their memories forever and changing their future identity in fundamental and irrevocable ways" (1). In his book National Trauma and Collective Memory, Arthur Neal emphasizes the impact of a national trauma on the unity of society:

While in some cases national trauma results in enhancing a sense of unity within a society, there are other cases in which collective traumas have fragmenting effects...The social heritage provides us with an everyday serious crisis of meaning surfaces when we can no longer make assumptions about the continuity of social life as it is known and understood. (31).

Neal believes that cultural traumata sometimes strengthen the sense of unity within a group and, in other cases; they might weaken the bonds within this group.

Dominick LaCapra maintains that there are two ways of dealing with a traumatic experience. The first one is 'acting out' in which the trauma survivor relives the traumatic experience in the present. The second one is 'working through' 
in which the patient decides to create a critical distance between the present and the past (Writing History 36). The two ways cannot only be applied to individuals but to groups as well when they handle a collective remembrance.

Marianne Hirsch coined the term "postmemory" to describe the relationship that the children of survivors of collective trauma have to their parents' memories. In her work, The Generation of Postmemory, she defines the term "postmemory" as "the experience of those who grow up dominated by narratives that preceded their birth, whose own belated stories are evacuated by the stories of the previous generation shaped by traumatic events that can neither be understood nor recreated" (22). The term 'postmemory' refers to the psycho-cultural consequences suffered by the descendants of survivors of collective cultural traumas. Hirsch believes that the experience of those, who have undergone a collective trauma, has a great influence on their offspring. Progenies of survivors of trauma also react deeply to these traumatic events but in ways different from those of the trauma witnesses. Traumatic memories are transferred to them so thoroughly that they seem to be their own memories. Hirsh maintains that these traumatic experiences are "transmitted to [later generations] so deeply as to seem to constitute memories in their own right" (103). Philippe Codde also defined postmemory as the transmission of traumatic memories to someone who has never personally experienced the traumatic experience and that it can be applied to all the generations that 'come after' (22). Although Hirsch coined the term "postmemory" to refer to the memories of the Holocaust survivors and stress their impacts on their descendants, she, herself, stated that she did not "'want to restrict the notion of postmemory to the remembrance of the Holocaust, or to privilege the Holocaust as unique or limit experience beyond 
Re-Dramatizing the Palestinian-Israeli Conflict: Representations of Trauma and Postmemory in Caryl Churchill's Seven Jewish Children: A Play for Gaza (2009)

Dr. Reem Ahmed A. El Bardisy

مجلة وادي النيل للار اسات والبحوث الإنسانية والاجتماعية و التربوية (مجلة علمية محكمة)

all others" (11). She maintained that this term could refer to the memories of survivors of any collective trauma, not only the Holocaust, "I have developed this notion in relation to children of Holocaust survivors, but I believe it may usefully describe other second-generation memories of cultural or collective traumatic events and experiences" (22). Hirsch uses the word ' postgeneration' to refer to the descendants of witnesses of collective traumatic experiences who did not live these traumatic events but heard about them from their ancestors. The postgeneration members are offspring of survivors of big traumatic events. They identify with the past to the extent that they regard the memories of their grandparents as if they were their own (3). Hirsch states that "the postgeneration can connect so deeply to the previous generation's remembrance of the past that they need to call that connection memory and thus that, in certain extreme circumstances; memory can be transmitted to those who were not actually there to live an event" (105-106). Melvin Bukiet (1953- ) agrees with Hirsh that "members of postgeneration are not only influenced by the behavioral traits of their parents but also by their recollections of the trauma" (149).

Hirsch maintains that the traumatic history can be transmitted to postgeneration members by some postmemorial acts of creation such as literature, photographs, art, culture and modes of behavior ("The Generation" 106). These are media of transmission that underscore the memory of a traumatic experience and handle its psychological impacts. In this way, these acts of creation can help people contend with trauma and make sense of the past, which is the main objective of postmemory. She states, "by creating postmemorial works, less directly affected participants can become engaged in the generation of postmemory that can persist even after all participants and even their familial descendants are gone" 


\section{مجلة وادي النيل للاراسات والبحوث الإسانية والاجتماعية والتربوية (مجلة علمية محكمة)}

(ISSN : 2536 - 9555)

(33). Hirsch believes that such postmemorial works can have a great impact on postgeneration members who did not live these traumatic experiences. Through these works, they get informed of the memories of their ancestors that might affect their personalities and constitute their identity.

\section{Seven Jewish Children (2009)}

Caryl Churchill's play Seven Jewish Children consists of seven scenes that deal with the Jewish history from the Holocaust till the military strike on Gaza in 2009. It sheds light on the Jewish immigration to Palestine, the foundation of Israel, the expulsion of the Palestinian Arabs, the 1948 ArabIsraeli War, the dispute over water, the First Intifada, the building of the West Bank barrier, the Palestinian suicide attacks, Hamas rocket attacks, the building of the West Bank barrier and the bombing of Gaza in 2009. In these scenes, some Jewish parents, grandparents and relatives discuss how they will explain these events to an off stage child. Throughout the play, these unnamed Jewish characters debate how much their children must know and must not know about Jewish history.

Although it is widely agreed that not every Jew is a Zionist, Churchill never mentions the words "Zionist", "Zionism" or even "Israel" and "Israeli" at all in the play. On the contrary, she uses the words "Jew" and "Jewish" all the time in the play and in its title as well. Whenever she talks about them, whether as victims or victimizers, she uses the words "Jews" and "Jewish". It is as if the dramatist wants to declare that she is not convinced with the difference between the Jewish ideology and the Zionist one, and to stress her belief that every Jew is an Israeli or a Zionist even if he denies.

A Zionist is said to be someone who supports the establishment of an independent Jewish state in the Middle East and regards Palestine as the promised land where Jews 
Re-Dramatizing the Palestinian-Israeli Conflict: Representations of Trauma and Postmemory in Caryl Churchill's Seven Jewish Children: A Play for Gaza (2009)

Dr. Reem Ahmed A. EI Bardisy

مجلة وادي النيل للار اسات والبحوث الإنسانية والاجتماعية و التربوية (مجلة علمية محكمة)

can relish freedom and security. Further, Zionism, as a political movement, is not only supported by Jews, but by many non-Jews as well, like some Western governments and numerous American evangelical Christians (Elmessiri, Encyclopedia 55-70). On the other hand, there are other Jews who adopt an anti-Zionist stance and regard Zionism as a racist ideology. They support the Palestinian cause along with the Israeli one and oppose most of the actions of the Israeli state regarding the treatment of the Palestinians (Glass56-81). Moreover, there was a Jewish resistance to the Zionist movement which endeavored to establish a Jewish national home in Palestine even before the declaration of the state of Israel in 1948 (Elmessiri, Zionist Thought 30-45). Hence, antiZionism must not be mixed up with anti-Jewishness.

\section{Trauma and Postmemory in Seven Jewish Children}

In Unclaimed Experience: Trauma, Narrative and History, Cathy Carouth stresses the importance of "the complex relation between knowing and not knowing" to literature, trauma studies and psychoanalysis (2-3). The issue of knowing and not knowing is a very significant one for the Jewish elders in Seven Jewish Children. From the very beginning of the play, these elders discuss the stages in their Jewish history that their children must know and the events they must not be informed with. They do not want to let their crimes determine the future of their descendants. As Erin McGlothlin stated, "the offspring of perpetrators inherit the history of their parents' unacknowledged crimes, a legacy of violence and violation whose effects are felt as a stain upon their souls" (910). The Jewish elders, in this play, are frightened that these painful events, which have traumatized them, might traumatize their children, too. Hence, they decide to hide some events in order to protect their children from their agonizing 
experiences and the excruciating feelings evoked by them. From the very beginning of the play, we see the division within the Israeli community and the inner conflict inside each Jew. The phrases "Tell her" and "Don't tell her", which run throughout the play, stress the bewilderment of these Jewish elders as well as their feelings of great horror and insecurity. The contrast between the words "game" and "serious" in the first two lines in the play shows the division among the Jews and stresses their confusion:

Tell her it's a game

Tell her it's serious. (1)

Moreover, the reference to nameless Jewish elders emphasizes the state of perplexity from which many Jews, not certain ones, suffer and brings to light the conflict inside the Israeli community. Similarly, the reference to unseen children shows the danger that might afflict a lot of Jewish children in the present and future if they know the truth.

In Seven Jewish Children, the issue of transgenerational transmission of trauma is shown to be bewildering for the Jewish elders. Their children did not witness most of the traumatic events that have agitated them, yet they grew up under their consequences and their life would be affected by their repercussions. Accordingly, they are pre-destined to inherit their parents' legacy. LaCapra stressed this "intergenerational transmission of trauma" (Writing History 108). Sigmund Freud (1856-1939) coined the term "archaic heritage" to emphasize this type of inheritance and referred to it as "the memory-traces of the experiences of former generations" (99). The play stresses the trauma of these Jewish elders who are troubled by their agonizing history and accentuates the continuing impact of the past on the present and future of these elders. For them, the boundaries between 
Re-Dramatizing the Palestinian-Israeli Conflict: Representations of Trauma and Postmemory in Caryl Churchill's Seven Jewish Children: A Play for Gaza (2009)

Dr. Reem Ahmed A. El Bardisy

مجلة وادي النيل للاراسات والبحوث الإنسانية والاجتماعية و التربوية (مجلة علمية محكمة)

the past and present are blurred. Their painful past interferes with their present and its memories traumatize them and shape their lives. Hence, they do not want their children to inherit their trauma and fall victims to their delinquencies.

Postmemory is one of the main concerns in Seven Jewish Children. Throughout the play, the dramatist emphasizes how these Jewish elders are haunted with the memories of their past and how they suffer from the negative impacts of postmemory. Marianne Hirsch's term 'postmemory' can be applied to the status of the Jewish children in this play. Throughout the play, the dramatist emphasizes these Jewish elders' preoccupation with the effect of postmemory on their children. They are always worried about the traumatizing impact of their memories on their postgeneration members and afraid of the interference of their shameful past into the present and future of these generations, too. Hence, they decided to form counter-memories of which the successive generations of Jewish children will not be ashamed, rather than those shared stories and events that form their collective traumatic history. Each scene, in this play, stresses the internal conflict inside these Jewish elders as well as the bewilderment and confusion within the Israeli community. Moreover, the whole play shows how these Jews, in the different stages of their history, are afraid of the impact of their traumatic memories on their children and grandchildren. They are afraid that their children might be antagonized by their disgraceful past and subsequently relive their experiences. The sentence "Don't frighten her", which is repeated many times throughout the whole play, shows how they are afraid of the impact of their traumatic history on their children.

What makes matters worse with the Jews' postmemory is that it handles the transmission of memories of events that did not come to an end but they are still in continuum. The 
مجلة وادي النيل للاراسات والبحوث الإنسانية والاجتماعية والتربوية (مجلة علمية محكمة)

(ISSN : 2536 - 9555)

Palestinian-Israeli conflict is still going on and the memories of these Jews have not come to an end yet. These Jewish elders can not ignore the past and look forward to the present because the present in Israel integrates with the past. Hence, the play raises a very important question, i.e., what is the effect of today's postmemory on tomorrow's children? If today's Jewish children are suffering from the impacts of yesterday's postmemory, later generations of Israeli children will, definitely, suffer from the impacts of today's postmemory.

Strategies Used by the Jewish Elders to Protect their Descendants from the Traumatic Effects of Postmemory

To protect their children from inheriting their collective trauma as well as the anguish that their postmemories evoke, these Jewish elders follow some strategies in their testimonies. Hiding some of their shameful memories is one of these strategies. This is shown clearly in the litany that goes throughout the play "Tell her", "Don't tell her".

Adopting the victim's discourse is another strategy that these Jewish elders resort to in order to protect their children from the impacts of their collective trauma and postmemory. They insist to divert these children's attention away from their ancestors' shameful history, which is full of massacres and atrocities, and focus on the memories by which they can get the children's sympathy. The Holocaust is the best and most appropriate collective trauma that can lead to the success of this strategy. As LaCapra declares, "The Holocaust depicts an event of such magnitude and such an absurd reality that even victims back then could not imagine or comprehend its magnitude" (Representing the Holocaust 220). He maintains that a historical trauma usually "has a negative impact on individuals which poses problems for later generations involving intergenerational transmission of trauma"(307). 
Re-Dramatizing the Palestinian-Israeli Conflict: Representations of Trauma and Postmemory in Caryl Churchill's Seven Jewish Children: A Play for Gaza (2009)

Dr. Reem Ahmed A. EI Bardisy

مجلة وادي النيل للاراسات والبحوث الإنسانية والاجتماعية والتربوية (مجلة علمية محكمة)

Hence, these Jewish elders decide to stress the postmemory of the Holocaust from which the Jews still suffer, not only the generations that witnessed this trauma, but also the generations that followed them. They agree to tell their children how their relatives were mercilessly killed, humiliated and persecuted by Hitler and the Nazi regime. In the second scene, the dramatist shows how the Jews manipulate the Holocaust to win the sympathy of their children:

Tell her this is a photograph of her grandmother, her uncles and me. Tell her her uncles died. (2)

The Jews are exceedingly interested in the memorialization of the Holocaust. They always portray themselves as perpetual victims of prolonged and constant violence during the Nazi regime. Moreover, they want their children to be proud of them and of their ancestors who died in the Holocaust:

Tell her her grandmother was clever

Tell her she was brave

Tell her she taught me how to make cakes. (2)

These Jewish parents make the best use of this historical trauma to make all people, not only their children, sympathize with them. They also endeavor to tell their children more about the Holocaust when they grow up:

Tell her more when she's older.

Tell her there were people who hated Jews. (2) 


\section{مجلة وادي النيل للاراسات و البحوث الإنسانية والاجتماعية والتربوية (مجلة علمية محكمة)}

(ISSN : 2536 - 9555)

Stressing the postmemory of the Holocaust is very useful for the Jewish elders in Seven Jewish Children. Not only does it help them to get the sympathy of the postgeneration members and the whole world, but it also enables them to justify Zionism. They always state that it was their suffering in the Holocaust that has obliged them to commit these atrocities against the Palestinian people in order to prevent another Holocaust. Although the Holocaust is a serious historical traumatic experience, Churchill does not focus on the trauma itself, but on the attempts of the Jews to remember and emphasize this traumatic experience to achieve their goals.

Moreover, the Holocaust is used by a great number of Jews to create a cultural identity. It is usually maintained that the Jewish identity is based on the commemoration of the Holocaust, not on the Jewish religion or race. Walter Benn Michaels states that the Jews base their identity on their cultural legacy and that there is a strong relationship between Jewishness and the cultural legacy of the Holocaust. Thus, remembering the Holocaust is so important for the Jews. Michaels maintains:

Many of those who think of themselves as Jews do not think that they are Jews because they have Jewish blood and are in fact skeptical of the very idea of Jewish blood. For them, ... cultural inheritance takes the place of biological inheritance. ... Thus, Jews can give up the belief in Jewish blood and give up the belief in a Jewish God; what they can't give up is Jewish culture. (195)

Hence, many Jews believe that the traumatic experience of the Holocaust has to be acknowledged and remembered. As Sigmund Freud maintained, it is used as a "screen memory" (5). Victimization and the political manipulation of the Holocaust is a strong strategy used by the majority of the Jews to justify Zionism. 
Re-Dramatizing the Palestinian-Israeli Conflict: Representations of Trauma and Postmemory in Caryl Churchill's Seven Jewish Children: A Play for Gaza (2009)

Dr. Reem Ahmed A. El Bardisy

مجلة وادي النيل للار اسات والبحوث الإنسانية والاجتماعية و التربوية (مجلة علمية محكمة)

Distorting the image of the Palestinians is also another strategy used by these Jewish elders in the play. To justify their violence against the Palestinian people and make their children comprehend the horror of their war against them, these elders portray the Palestinian people as terrorists. These Jewish parents and grandparents portray the Palestinians as the New Nazis that want to exterminate the Jews:

Tell her, tell her they set off bombs in cafés Tell her to be careful.

Tell her they don't understand anything except violence Tell her we want peace. (6)

Hence, using violence against them is a defense mechanism by which the Jews can protect themselves and their children from the Palestinians and prevent another Holocaust. They maintain, "Tell her we need the wall to keep us safe" (6). They also try to portray the Palestinians as barbarian and uncivilized Bedouin who live in tents in the deserts and ride camels:

Don't tell her who they are

Tell her something

Tell her they're Bedouin, they travel about

Tell her about camels in the desert and dates

Tell her they live in tents. (4)

Moreover, these Jewish parents depict the Palestinians as usurpers of the Jews' land. They tell their children that the Palestinians are not the original owners or inhabitants of Palestine but they usurped it from the Jews: 
مجلة وادي النيل للاراسات والبحوث الإنسانية والاجتماعية والتربوية (مجلة علمية محكمة)

(ISSN : 2536 - 9555)

Don't tell her who used to live in this house

No but don't tell her her great great grandfather used to live in this house

No but don't tell her Arabs used to sleep in her bedroom

Don't tell her they said it was a land without people.(4)

Using religion is a fourth strategy used by the Jewish elders in the play. It is employed to spread the false values these Jewish parents invent to justify Zionism and help them protect their children from the repercussions of their traumatic history and postmemory, " Tell her it's the land God gave us" (3). They try to convince their children that all these massacres and atrocities were committed for religious reasons, i.e., to carry out God's promise in the Old Testament, "Tell her again this is our promised land" (4).

By following these strategies, the Jewish parents believe that their children will be able to deal with their traumatic past and recover these historical memories much easier than them. This accords with Marianne Hirsch's words that "[p]erhaps it is only in subsequent generations that trauma can be witnessed and worked through, by those who were not there to live it but who received its effects, belatedly, through the narratives, actions and symptoms of the previous generation" (12). Hence, these Jewish elders believe they can save their children from being afflicted with trauma and avoid being scorned by them.

Most of the strategies these Jewish elders adopt to protect their children from the impacts of trauma and postmemory appear collectively in the final scenes in which these elders think how they can hide their traumatic history from their children in the modern age of technology. In the past, it was easy for these elders to shield their postgeneration from the impacts of postmemory, but with the emergence of 
Re-Dramatizing the Palestinian-Israeli Conflict: Representations of Trauma and Postmemory in Caryl Churchill's Seven Jewish Children: A Play for Gaza (2009)

Dr. Reem Ahmed A. EI Bardisy

مجلة وادي النيل للاراسات والبحوث الإنسانية والاجتماعية والتربوية (مجلة علمية محكمة)

technology, their attempts have become harder. They are afraid that their children might watch the atrocities their elders have committed on television. The final scene shows the efforts of these elders to rescue their children from the impacts of postmemory in 2008. First of all, the parents must divert their children's attention away from watching the news and direct them to see cartoon in order not to see the massacres that their elders have committed throughout their history. However, if these children watch the news bulletin, these elders must resort to other strategies. They must ask them not take everything they see on television for granted:

Tell her she can't watch the news

Tell her she can watch cartoons

Tell her she can stay up late and watch Friends.

Tell her you can't believe what you see on television

Tell her we killed the babies by mistake. (7)

Besides, they must degrade and humiliate the Palestinian people and convince their children that they are their enemies that want to exterminate them; therefore, they deserve to be killed:

Tell her they're terrorists

Tell her they're filth

Tell her they're animals living in rubble now, tell her I wouldn't care if we wiped them out. (7)

These Jewish elders have decided to prevent their children from sympathizing with the Palestinians if they see the atrocities they commit against them on television as well as

111 
(ISSN : 2536 - 9555)

convince them that these Palestinians deserve this harsh treatment. Besides, they have resolved to arouse their children's sympathy for the Jews who must not suffer from another Holocaust:

Tell her they did it to themselves. Tell her they want their children killed to make people sorry for them, Tell her I'm not sorry for them, tell her not to be sorry for them, Tell her we're the ones to be sorry for, tell her they can't talk suffering to us...tell her we're chosen people. (7)

These lines also show how, in the age of technology, employing religion is also a very necessary strategy which can help the Jews justify the atrocities they commit if their children see them on television. These elders remind their children, every now and then, that they are the chosen people and that Palestine is the promised land.

Above all, the Jewish parents must hide the facts that they regard shameful like, for example, the refusal of some of the Jews to join the Israeli army," Don't tell her her cousin refused to serve in the army" (7). Moreover, the problem of water allocation is one of the issues that must be hidden. They are afraid that their children might not accept their justification for the water problem if they become aware of it. They do not know how they can justify the inhumane scene in which their elders enjoy their swimming pools while the Palestinians still fetch their drinking water in cans:

Don't tell her the trouble about the swimming pool

Tell her it's our water, we have the right

Tell her it's not the water for their fields

Don't tell her anything about water. (6) 
Re-Dramatizing the Palestinian-Israeli Conflict: Representations of Trauma and Postmemory in Caryl Churchill's Seven Jewish Children: A Play for Gaza (2009)

Dr. Reem Ahmed A. El Bardisy

مجلة وادي النيل للار اسات و البحوث الإنسانية والاجتماعية والتربوية (مجلة علمية محكمة)

In this quotation, the number of affirmative imperative sentences is equal to that of the negative ones. This reflects the division among the Jews regarding the problem of water allocation and underscores the conflict between 'acting- out' and 'counter-acting- out' within the Israeli community.

\section{'Acting-Out' and 'Counter-Acting-Out' in Seven Jewish Children.}

In Writing History, Writing Trauma, Dominick LaCapra emphasizes that there are two ways to handle a traumatic experience. The first one is 'acting out' in which the trauma patient relives the traumatic event in the present. The second one is 'working through' in which the trauma survivor makes a critical distance between the present and the past (36-40). The Israeli Right Wing Party adopts a political 'acting out' and makes a resemblance between the Arabs and the Nazis. This equation appeared in the Israeli culture from the 1940s until the 1970s. It helped the Israeli justify their Nazi-like acts against the Palestinians and convince the whole world, especially the West, that they use violence against the Palestinians to protect themselves and prevent a second Holocaust. In a word, it helps to explain their radical transition from victims to victimizers. From the 1970s onwards, the bond between the Holocaust and the Israeli- Arab conflict began to change and a huge gap between the Left Wing and Right Wing parties appeared. The Left Wing created 'counteracting- out', and drew a similarity between the Israeli soldiers and the Nazis. It equated the Jewish persecution in the Holocaust with the Palestinian persecution in their conflict with Israel. Since 1970, the Jewish community has been divided between 'acting-out' and 'counter-acting-out' (Shohat 20-25). This division stresses the bewilderment of a great 
number of Jews and the opposition within the Israeli community.

The conflict between the Right and Left wings in Israel is reflected in Seven Jewish Children. In each scene, we see a conflict between 'acting-out' and 'counter- acting- out' among the Jewish elders as well as inside each one of them. This conflict is reflected in the use of the affirmative and negative imperative sentences that run throughout the play:" Tell her"," Don't tell her". They know that their traumatic experience and postmemories will affect their postgeneration members, and that their children's identity will be shaped by their parents' testimonies. Hence, they undergo this conflict between 'acting- out' and 'counter- acting- out'. The dramatist stresses the perplexity of the Jews regarding many historical events. They, sometimes, tell their children specific events in a way that shows the Palestinians as the new Nazis and, sometimes, they tell them the same events in a way that shows these Jews as the new Nazis. This perplexity is also stressed vis-à-vis the strategies they try to follow to prevent their children from being afflicted with trauma. They, at times, recommend following these strategies, and on other occasions feel reluctant to use them. For example, they try to employ religion, from time to time, to achieve their goals; however, they sometimes avoid referring to it:

Tell her it's the land God gave us

Don't tell her religion. (3)

Similarly, they occasionally endeavor to distort the image of the Palestinians and show them as terrorists, and, sometimes, they do not like to talk about them:

Don't tell her they set off bombs in cafés

Tell her, tell her they set off bombs in cafés. (6) 
Re-Dramatizing the Palestinian-Israeli Conflict: Representations of Trauma and Postmemory in Caryl Churchill's Seven Jewish Children: A Play for Gaza (2009)

Dr. Reem Ahmed A. EI Bardisy

مجلة وادي النيل للار اسات والبحوث الإنسانية والاجتماعية و التربوية (مجلة علمية محكمة)

The political conflict between 'acting out' and 'counteracting- out', which appears in the first scenes, turns into a complete 'counter acting-out' in the final scenes where the tone of the Jews greatly changes. They abandon victimization and speak in a way which reflects this state of 'counter actingout' that shows them as the new Nazis:

Tell her we won

Tell her her brother's a hero

Tell her how big their armies are

Tell her we turned them back

Tell her we're fighters

Tell her we've got new land. (5)

In the final scene, the state of "counter- acting- out" is accentuated. The Jewish elders adopt a tone of power, threat and rudeness. They are not ashamed to declare that they will not stop killing the Palestinians until they feel secure. Further, they boast of their army and assure the whole world that it will always defend and protect them, "Tell her, tell her about the army, tell her to be proud of the army.... Tell her we're the iron fist now, tell her it's the fog of war, tell her we won't stop killing them till we're safe (7). Besides, being an unloved people is one of the issues that bothered these Jewish elders in the first scenes. From the very beginning of the play, they have tried to assure their children that they are not unloved people. Although there are some people who hate them, there are others who love them:

Tell her there are still people who hate Jews

Tell her there are people who love Jews. (2) 
On the contrary, in the final scene, they do not care about being loved or hated at all. They do not try to justify the antipathy and enmity that many people feel towards them:

tell her I laughed when I saw the dead policemen, ... tell her I don't care if the world hates us, tell her we're better haters, tell her we're chosen people, tell her I look at one of their children covered in blood and what do I feel? tell her all I feel is happy it's not her. Don't tell her that. (7)

These lines, which the Jewish elders utter at the end of the play, show how cruel they became. They turned into people without feelings.

\section{The 'Counter Acting- Out' and the Charge of Anti- Semitism}

Because of the state of 'counter acting- out' that the dramatist accentuates in Seven Jewish Children, she has been severely attacked and the play has been regarded as antiSemitic. Some critics attacked the play and believed that it equates the Jews with the Nazis. Jeffrey Goldberg, for example, called the play a "blood libel" and considered it "the mainstreaming of the worst anti-Jewish stereotypes" (1). Jonathan Hoffman regarded the play as "a libellous and despicable demonisation of Israeli parents and grandparents" and believed that it would "stoke the fires of antisemitism"(25). Melanie Phillips maintained that the play is "an open vilification of the Jewish people... drawing upon an atavistic hatred of the Jews" and regarded it as an "open incitement to hatred" (6). The Board of Deputies of British Jews attacked the play and considered it "horrifically antiIsrael," and "beyond the boundaries of reasonable political discourse" (Walker 3). Deb Margolin wrote a play called 
Re-Dramatizing the Palestinian-Israeli Conflict: Representations of Trauma and Postmemory in Caryl Churchill's Seven Jewish Children: A Play for Gaza (2009)

Dr. Reem Ahmed A. El Bardisy

مجلة وادي النيل للاراسات والبحوث الإنسانية والاجتماعية و التربوية (مجلة علمية محكمة)

Seven Palestinian Children (2009), in response to Churchill's play, in which he attacks the Palestinian people and depicts them as terrorists.

The play's subtitle, i.e., "A play For Gaza", has led many critics to believe that this play is a piece of a reactive theatre that was written in direct response to the situation in Gaza. Moreover, the permission that Churchill has given for anyone to perform the play without royalties, on condition that all the money of the play's different performances must be given to the Medical Aid for the Palestinians (MAP), has led many critics to argue that she uses drama for political purposes. Churchill, herself, confessed that this play is a 'political event', "It came out of feeling strongly about what's happening in Gaza - it's a way of helping the people there. Everyone knows about Gaza, everyone is upset about it, and this play is something they could come to. It's a political event, not just a theatre event (Brown 3). For many critics, using such a phrase as "everyone is upset about it" in Churchill's speech indicates that the dramatist encourages the audience to sympathize with the Palestinians and condemn the Israeli. They maintain that such a phrase urges the audience to adopt the same political beliefs of the dramatist which led to what Christopher Hart called "the enclosed, fetid, smug, self-congratulating and entirely irrelevant little world of contemporary political theatre" (2). Some critics regarded the play as similar to those morality plays in which stories were told with a didactic purpose and good and evil are presented in clear tones. Kate Leader, for example, contended:

Indeed, in its tracing of important episodes in Israeli history, Seven Jewish Children is somewhat akin to the travelling medieval morality plays where biblical stories were retold with didactic intention. Good and evil are 
مجلة وادي النيل للاراسات والبحوث الإنسانية والاجتماعية والتربوية (مجلة علمية محكمة)

(ISSN : 2536 - 9555)

painted in explicit terms to maximize the impact of the moral message within the time constraint, leading to the possibility of stereotyping. (134)

Leader believes that the play portrays the Palestinians as unheard oppressed victims who suffer from dehumanization. She also states that this play attempts to arouse the audience's sympathy towards the Palestinian people and condemns those people who are indifferent to the Palestinian dilemma.

On the other hand, other critics considered the play a realistic portrayal of the Palestinian-Israeli conflict. Dominic Maxwell, for example, liked the play and regarded it as an "impassioned response to the events in Gaza that is elliptical, empathetic and illuminating" (2). Charlotte Higgins also stated, "The play did not strike me as antisemitic.... I cleave strongly to the view that it is possible to be critical of Israel without being antisemitic, and I do not believe that Churchill is making or otherwise implying universal claims about the Jewish people in this play" (3). The Jewish American critics Tony Kushner and Alisa Solomon maintained, "To see antiSemitism here is to construe erroneously the words spoken by the worst of Churchill's characters as a statement from the playwright about all Jews as preternaturally filled with a viciousness unique among humankind. But to do this is, again, to distort what Churchill wrote" (5). Such critics reject the charge of anti-Semitism directed against the play and regard it as truthful depiction of the Palestinian-Israeli conflict.

Churchill wrote an article called "My Play is not antiSemitic" in The Independent to refute the argument of Howard Jacobson who condemned her and denounced the play harshly as well as to counter the assumptions of those who attacked her and described the play as anti-Semitic. She maintained, "Howard Jacobson seems to see the play from a very particular perspective so that everything is twisted. The 
Re-Dramatizing the Palestinian-Israeli Conflict: Representations of Trauma and Postmemory in Caryl Churchill's Seven Jewish Children: A Play for Gaza (2009)

Dr. Reem Ahmed A. EI Bardisy

مجلة وادي النيل للار اسات والبحوث الإنسانية والاجتماعية والتربوية (مجلة علمية محكمة)

characters are 'covert and deceitful', they are constructing a 'parallel hell' to Hitler's Europe, they are 'monsters who kill babies by design'. I don't recognize the play from that description". Churchill stated that, in this play, she only described what was going on in Gaza:

Finally, the blood libel. I find it extraordinary that, because the play talks about the killing of children in Gaza, I am accused of reviving the medieval blood libel that Jews killed Christian children and consumed their blood. The character is not "rejoicing in the murder of little children". He sees dead children on television and feels numb and defiant in his relief that his own child is safe. He believes that what has happened is justified as self-defence. Howard Jacobson may agree. I don't, but it doesn't make either of them a monster, or me antiSemitic. (3)

Churchill asserted that Seven Jewish Children is a truthful depiction of the massacres and atrocities that take place everyday in Gaza.

\section{Postmemorial Acts of Creation in Seven Jewish Children}

As Hirsch maintains, a traumatic experience can be transmitted to postgenerations, who did not witness this trauma, by some postmemorial acts of creation such as literature, photographs, art, culture and modes of behavior ("The Generation" 33-40). Hirsch's words about the different media of transmission accord with Jan Assmann's opinion about communicative and cultural memory. Assmann maintained that there are two kinds of collective remembrance, specifically cultural memory and 
مجلة وادي النيل للاراسات والبحوث الإنسانية والاجتماعية والتربوية (مجلة علمية محكمة)

(ISSN : 2536 - 9555)

communicative memory. Cultural memory is an institutionalized kind of memory that is shared by people who have the same cultural identity (110). He maintains, "in order to be able to be reembodied [sic] in the sequence of generations, cultural memory, unlike communicative memory, exists also in disembodied form and requires institutions of preservation and reembodiment [sic]" (111). Cultural memory, then, is a form of collective memory in which memories are stored in external symbols or institutions which transmit memories to different generations such as monuments, libraries and museums. Conversely, communicative memory is characterized with regular communication. Owing to its non-institutionalized character, communicative memory has a fairly short time span. It lasts for about eighty years where three generations can live. Assmann maintains that the durability of communicative memories depends on the power of social connections.

Memories can be transmitted from one generation to another through communication. In Seven Jewish Children, the communicative memory is very obvious. It is the memory on which these Jewish elders mainly rely to convey specific events to their children in order to protect them from the impacts of postmemory. Talking to their children and telling them their own versions of the Israeli- Palestinian conflict is one of the important medial transmitters to which these Jewish elders resort. Aleida Assmann maintains that memories are linked between different individuals, and by talking about these memories, they can be passed from one person to another and eventually be written down. Individuals can share their experiences with others and turn these memories into media of transmissions that will help to make sense of their trauma (123). Hence, these Jewish seniors insist to make their children hear their own stories, not the stories of anybody else in order to be able to justify the ignominious acts of which 
Re-Dramatizing the Palestinian-Israeli Conflict: Representations of Trauma and Postmemory in Caryl Churchill's Seven Jewish Children: A Play for Gaza (2009)

Dr. Reem Ahmed A. El Bardisy

مجلة وادي النيل للار اسات و البحوث الإنسانية والاجتماعية والتربوية (مجلة علمية محكمة)

they are ashamed. Since the past passes onto the coming generations through the stories of their parents and grandparents, these Jewish elders decide to pass stories of their own creation to their descendants. Therefore, they want to prevent their children from talking to Palestinian children. They also try to prevent their children from watching television in order not to see any photos, videos or films that handle their shameful past. They know that the stories which their children see on television will have a great influence on the way they regard their ancestors as well as their country. Therefore, they insist to make their own stories the main source of knowledge for their children. Photographs are also important media of transmitters. Hence, these Jewish elders insist to show their children photographs of their ancestors who were tortured and killed in the Holocaust, "Tell her this is a photograph of her grandmother, her uncles and me" (2).

In Prosthetic Memory: the Transformation of American Remembrance in the Age of Mass Culture, Alison Landsberg handles the concepts of collective and individual memory and maintains that prosthetic memories "originate outside a person's lived experience and yet are taken on and worn by that person through mass cultural technologies of memory". Landsberg believes that such memories "develop after an encounter with a mass cultural representation of the past, when new images and ideas come into contact with a person's own archive of experience" (19). Prosthetic memories help people, who did not live traumatic events, to feel as if they are witnesses of these traumata through different works of culture. Landsberg also states that prosthetic memories are not related to genealogy, as in the concept of postmemory, but they can be obtained by anyone. In Seven Jewish Children, the ancestors' testimonies of the past were the only source of knowledge for their children before the emergence of 
مجلة وادي النيل للاراسات والبحوث الإنسانية والاجتماعية والتربوية (مجلة علمية محكمة)

(ISSN : 2536 - 9555)

technology. Nonetheless, in the age of technology, the task of these Jewish elders has become a very difficult one, as their children have a direct access to the past.

Seven Jewish Children shows how literature, especially theatre, can play a vital role in transmitting postmemories and dealing with trauma. Although Churchill is not a Jewish postgeneration member, her play can be regarded as a postmemorial act of creation through which traumatic history can be transmitted to later Jewish and non- Jewish generations. It revisits the past and transmits the traumatic memories of important historical events and stages of the Jewish history to successive generations that did not witness these events. Moreover, this play deals with the impacts of these memories and shows how memories do not disappear with the passing away of a generation, but they continue to have an omnipresent influence on postgenerations by dint of literature.

\section{Using Postdramatic Elements to Awaken the} Audience's Ethical Response towards the PalestinianIsraeli Conflict.

In Seven Jewish Children, Caryl Churchill has adopted some postdramatic elements such as the absence of a naturalistic handling of characters, the compression of time and the lack of a closure. Using non-naturalistic techniques can help the audience focus on the power of the text and perceive the vulnerability of the Palestinians. Further, it can lead the audience to concentrate on the ethical side of the play and realize the reality of this conflict. In Seven Jewish Children, the characters are not demarcated in the naturalistic sense. The dramatist does not give them any names. Moreover, she emphasizes, in the stage directions, that their roles "may be played by any number of actors" (2). Besides, the play's setting is not specified. Moreover, the language, 
Re-Dramatizing the Palestinian-Israeli Conflict: Representations of Trauma and Postmemory in Caryl Churchill's Seven Jewish Children: A Play for Gaza (2009)

Dr. Reem Ahmed A. EI Bardisy

مجلة وادي النيل للاراسات والبحوث الإنسانية والاجتماعية و التربوية (مجلة علمية محكمة)

characterized as it is by rhythmicity, straightforwardness and power, is not presented "as the speech of character" as HansThies Lehmann maintained (Postdramatic18). Churchill does not insist on allocating specific speeches to certain characters, but she leaves the dividing up of lines to the director. She asserts, in the directions for the play, that "the lines can be shared out in any way you like among those characters" (2). In a word, she does not bind the directors to perform the play in any specific way regarding the number of characters, their names, the setting and the division of lines. R. Darren Gobert believes that the play is "an inkblot [which] guarantees only that disparate meanings will emerge in the imaginations of those that apprehend it"(167). He thinks that the open text form, which Churchill uses in this play, gives room to different meanings.

Kate Leader depicts the performance of the play at the Royal Court Theatre and maintains that the stage did not have any furniture or decor except a table and some chairs in the middle. Some actors stood against the wall while the others were close to the table. The house was dark and only the table was illuminated. She states that the staging was "minimal and deliberately low-key" and that a "sense of the transitory permeate[d] the production"(132). She adds that the beginnings and endings of the different periods of Jewish history were indicated by a flash of light as well as by the change of actors. Leader maintains that "the nonspecific characters, interchangeable faces and minimal props lend the production a strongly allegorical feeling. What might be a Jewish Israeli family becomes the representative for all Jewish Israeli families, just as the absent child represents all children" (133). She thinks that the open text form that Churchill used, in this play, leads the audience to put themselves in the position of these Jewish elders and think of what they must 
tell their children about the conflict. It also makes them feel worried about their children who are represented by the absent children of the play. Hence, it makes the audiences witnesses of the Palestinian-Israeli conflict that the play addresses and raises their ethical awareness of this conflict.

Churchill does not offer a solution or a closure and the audiences are left with unanswered questions. By ending the play without a closure, the dramatist warns the audience that if no action is taken regarding the Palestinian-Israeli conflict, violence will continue and increase in the future. Hence, the coming generations will suffer as much as the absent children of the play will do if they know the whole truth. Not only does the lack of a closure lead the audience to think deeply of the issue that the play addresses and take an action, but it also accentuates their role as witnesses of the Palestinian-Israeli conflict. Further, it emphasizes the role of theatre in raising people's awareness of important issues. In Seven Jewish Children, Churchill encourages the audiences to play a vital role and adopt an ethical response towards the IsraeliPalestinian Conflict. It puts them in the shoe of the Jewish elders and leads them to think what they must tell their own children, family members and friends about the conflict after watching the play. As Lehmann maintained; the experience of the play "would be not only aesthetic but .... at the same time ethico-political" (Postdramatic186). He asserted that the play "becomes part of an artistic strategy which transforms the spectator into a witness and calls up an experience of ... awareness and responsibility" ("Word" 53). According to Lehmann, this play turns the audience into witnesses who must give their testimony regarding the events they see on the stage. Churchill's Seven Jewish Children tries to raise the ethical awareness among its audiences and lead them to react morally towards the conflict. 
Re-Dramatizing the Palestinian-Israeli Conflict: Representations of Trauma and Postmemory in Caryl Churchill's Seven Jewish Children: A Play for Gaza (2009)

Dr. Reem Ahmed A. El Bardisy

مجلة وادي النيل للاراسات والبحوث الإنسانية والاجتماعية و التربوية (مجلة علمية محكمة)

\section{Conclusion}

Seven Jewish Children is a play that presents a non-Jewish and non-Western view of the Palestinian-Israeli conflict. It challenges the stereotypical representations of this conflict and exposes some of the falsehoods that Western media propagate. Through fictionalizing the discussions of a group of Jewish elders, the dramatist exposes some beliefs and counter-beliefs regarding the Palestinian-Israeli conflict. She brings to the foreground the voices of rejection that come from within the Israeli community, which are tangibly different from the voices heard in the Western media. Additionally, the paper shows how the Jews, in this play, face trauma on multiple levels. Not only do they undergo trauma because of the experience of the Holocaust, but also due to the aggressive actions they are said to commit afterwards. Besides, this paper underscores the radical transition of these Jews from victims to victimizers and emphasizes their attempts to convince their descendants that they were forced to use violence and commit atrocities simply to prevent another Holocaust. Further, this paper brings to light the different strategies which the Jewish elders use to protect their children from the impacts of trauma and postmemory like adopting the victim's discourse, employing religion, distorting the image of the Palestinian people as well as hiding some shameful facts like the problem of water allocation and the refusal of some Jewish young men to join the army.

Moreover, this paper underscores the conflict between 'acting- out', that equates the Palestinians with the Nazis to justify Zionism, and 'counter- acting-out' that equates the Israeli with the Nazis. The paper also shows how the dramatist's representation of the conflict between "acting-out' and 'counter- acting-out', in this play, led many critics to regard her as anti-Israeli and consider the play anti-Semitic. 
This paper also emphasizes the role of postmemorial acts of creation such as literature and photographs in dealing with trauma. It raises the issue of how a traumatic past can be represented in literature and stresses the role of literature in transmitting postmemories.

Further, the postdramatic elements that Caryl Churchill has adopted in this play, such as the absence of a naturalistic handling of characters, the compression of time and the lack of a closure, can lead the audience to realize the susceptibility of the Palestinians and focus on the power of the text. Churchill invites the audiences to rethink of the PalestinianIsraeli Conflict they are watching on the stage and urges them to adopt an ethical response towards it. Furthermore, by presenting the bombing of Gaza that British media rejected to broadcast and the history of the Palestinian- Israeli conflict, the play gives voice to the voiceless and shows the role of theatre in raising people's awareness of vital issues. Besides accentuating the political and ethical potential of theatre, the debate, that the play has created, highlights the power of the theatre to speak the unspeakable.

\section{Works Cited}

Alexander, Jeffrey C. Cultural Trauma and Collective Identity.USA: University of California Press, 2004.

Assmann, Aleida. "Transformations between History and Memory". An International Quarterly, 2008, 49-72

.........., Jan. "Communicative And Cultural Memory." Cultural Memo Studies: An International and Interdisciplinary.Handbook. Astrid Erll. 1st ed. Berlin: N.P., 2008, 109-118.

Balaev, M. Contemporary Approaches in Literary Trauma Theory. London: Palgrave Macmillan, 2014. 
Re-Dramatizing the Palestinian-Israeli Conflict: Representations of Trauma and Postmemory in Caryl Churchill's Seven Jewish Children: A Play for Gaza (2009)

Dr. Reem Ahmed A. El Bardisy

مجلة وادي النيل للار اسات و البحوث الإنسانية والاجتماعية والتربوية (مجلة علمية محكمة)

Brown, Mark. "Royal Court Acts Fast with Gaza Crisis Play". The Guardian, 24 January, 2009.

https://www.theguardian.com/stage/2009/jan/24/theatre-

gaza-carylchurchill- royal- court-seven- jewishchildren. Accessed 31 May 2017.

Bukiet, Melvin J. Nothing Makes You Free: Writings by Descendants of Jewish Holocaust Survivors. New York:W. W. Norton \& Company, 2003.

Caruth, Cathy. Unclaimed Experience: Trauma, Narrative and History Baltimore: Johns Hopkins University Press, 1996.

Christopher, Hart. The Times. February, 2009.

Churchill, Caryl ." 'My play is not anti-Semitic'. Letters: Jacobson and Gaza: the debate continues ". The Independent. February, 2009. Seven Jewish Children; A Play for Gaza. London: Nick Hern Books, 2009.

Codde, Philippe. "Postmemory, Afterimages, Transferred Loss: First and Third Generation Holocaust Trauma in American Literature and Film." The Holocaust, Art, and Taboo: Transatlantic Exchanges on the Ethics and Aesthetics of Representation. Ed. Sophia Komor and Susanne Rohr. Heidelberg: Winter, 2010,61- 72 .

"Postmemory and Postmodern: Third Generation Jewish American Trauma Narratives." Contemporary American Literature. Belgium: Ghent University, 2013. 
مجلة وادي النيل للاراسات والبحوث الإنسانية والاجتماعية والتربوية (مجلة علمية محكمة) (ISSN : 2536 - 9555)

Elmessiri, Abdel Wahab. Encyclopedia of Zionist Concepts and Terms: a Critical Vision. Cairo: Dar Al Shorouk, 1975.

............... The end of history: An Introduction to Studying the Structure of Zionist thought. Cairo: Dar Al Shorouk, 1972.

Freud, S." From the History of an Infantile Neurosis". The Standard Edition of the Complete Psychological Works of Sigmund Freud: A Infantile Neurosis and Other Works. Volume XVII, 1917-1919, 1-124.

Glass, Charles. "Jews against Zion: Israeli Jewish AntiZionism".Journal of Palestine Studies.Vol. 5, No. 1/2 (Autumn, 1975-Winter, 1976), 56-81.

Gobert, R. Darren. The Theatre of Caryl Churchill. London: Methuen, 2014.

Goldberg , Jeffrey. "The Royal Court Theatre's Blood Libel" The Atlantic. 9 February, 2009.

Herman, Judith Lewis. Trauma and Recovery. New York: Basic Books, 1997.

Higgins, Charlotte. "Is Caryl Churchill's play Seven Jewish Children antisemitic?" The Guardian. 18 February, 2009.

Hirsch, Marianne. "The Generation of Postmemory". Poetics Today 29 (1), 2008, 103-128.

Hoffman, Jonathan."The law's duty is to protect the innocent, not to make them prove their innocence". The Daily Telegraph. London. 19 February, 2009.

Kusher, Tony and Alisa Solomon. "Tell her the truth". The Nation. 26 March, 2009. 
Re-Dramatizing the Palestinian-Israeli Conflict: Representations of Trauma and Postmemory in Caryl Churchill's Seven Jewish Children: A Play for Gaza (2009)

Dr. Reem Ahmed A. EI Bardisy

مجلة وادي النيل للاراسات والبحوث الإنسانية والاجتماعية والتربوية (مجلة علمية محكمة)

LaCapra, Dominick. Representing the Holocaust: History, Theory, Trauma. Ithaca: Cornell UP, 1994.

Writing History, Writing Trauma. Baltimore: Johns Hopkins UP, 2001.

Landsberg, Alison. Prosthetic Memory: the

Transformation of American Remembrance in the Age of Mass Culture. New York: Columbia University Press, 2004.

Leader, Kate. " 'Tell her to be careful': Caryl Churchill's Seven Jewish Children: A Play for Gaza at the Royal Court Theatre". Platform, Vol. 4, No. 1, Staging Gender(s), Spring 2009, pp. 132-136.

Lehmann, Hans-Thies. Postdramatic Theatre. London and

New York: Routledge, 2006. .. "Word and Stage in Postdramatic Theatre",

Drama and/ after Postmodernism, 2007, pp. 37-54.

Maxwell, Dominic. "Seven Jewish Children at Royal Court". The Times. 13 February, 2009.

McGlothlin, Erin. Second-Generation Holocaust

Literature: Legacies of Survival and Perpetration. Rochester. NY: Camden House, 2006.

Michaels, Walter Benn. "Plots against America:

Neoliberalism and Antiracism". American Literary History. Summer 2006, 288-302.

Neal, Arthur. National Trauma and Collective Memory.UK: Routledge Press, 2008.

Phillips, Melanie."Outrage over 'demonising' play for Gaza". The Jewish Chronicle. 12 February, 2009. 
مجلة وادي النيل للاراسات والبحوث الإنسانية والاجتماعية والتربوية (مجلة علمية محكمة)

(ISSN : 2536 - 9555)

Reed,Gail S. ed., "On Freud's 'Screen Memories'". The International Psychoanalytical Association Contemporary Freud: Turning Points and Critical Issues Series. London: Karnac Books, 2014.

Shohat, Ella. Israeli Cinema: East/West and the Politics of Representation. London and New York: I B Tauris, 2010.

Walker, Tim. "Caryl Churchill is Accused of 'antiSemitism'". The Daily Telegraph. 13 Feb, 2009. 